\section{PEMENUHAN HAK ANAK SEBAGAI PELAKU TINDAK PIDANA TERORISME ${ }^{1}$ \\ Oleh: Sri Hahamu ${ }^{2}$ \\ Devy K.G Sondakh ${ }^{3}$ \\ Jemmy Sondakh ${ }^{4}$}

\begin{abstract}
ABSTRAK
Penelitian di lakukan dengan melakukan metode penelitian hukum normatif yang fokusnya pada bahan-bahan hukum yaitu peraturan perundang-undangan internasional dan nasional tentang pemenuhan dan perlindungan anak sebagai pelaku tindak pidana terorisme. Hasil penelitian menunjukkan bahwa, secara internasional dan nasional eksistensi anak telah dijamin oleh hukum dan peraturan perundang-undangan. Akan tetapi dalam realisasinya masih menjadi kendala dalam mengiplementasikan regulasiregulasi terkait dengan kebutuhan anak. Belum tegasnya penerapan pengaturan tentang pemenuhan dan perlindungan hak anak sebagai pelaku tindak pidana terorisme di Indonesia yang terkait dengan keberadaan kelompok radikal yang mengatasnamakan kelmpok agama tertentu. Hal ini sangat beresiko bagi keamanan dan keselamatan anak-anak. Hak Asasi Anak sebagai Pelaku Tindak Pidana Terorisme masih belum jelas kepastian hukumnya di Indonesia bila dikaitkan dengan keberadaan dan doktrin orang tuanya sendiri serta kelompok-kelompok radikal.
\end{abstract}

Kata Kunci: Hak Anak, Pelaku, Tindak Pidana, Terorisme

\section{PENDAHULUAN}

\section{A. Latar Belakang Masalah}

Secara hukum pemenuhan hak anak harus dilindungi, karena sesungguhnya anak merupakan individu yang belum matang baik secara fisik, mental, maupun sosial. Posisi ini menjadikan anak sangat rawan terhadap tindakan dari orang dewasa. Article 1, Convention on the Rights of the Child menyatakan bahwa "Untuk tujuan Konvensi ini, seorang anak berarti setiap manusia di

\footnotetext{
${ }^{1}$ Artikel Tesis.

${ }^{2}$ Mahasiswa pada Fakultas Hukum Unsrat, NIM. 18202108060

${ }^{3}$ Fakultas Hukum Unsrat, Doktor IImu Hukum

${ }^{4}$ Fakultas Hukum Unsrat, Doktor IImu Hukum
}

bawah usia 18 tahun, kecuali apabila menurut hukum yang berlaku bagi anak tersebut ditentukan bahwa usia dewasa dicapai lebih awal. ${ }^{5}$ (Everyone under 18 years of age has all the rights in this Convention).

Koordinasi penyelanggaraan perlindungan anak diperlukan mengingat kegiatan pemenuhan dan perlindungan anak merupakan kegiatan lintas sektoral yang melibatkan banyak lembaga terkait. Anak sebagai generasi penerus bangsa memiliki peran penting dalam pembangunan nasional, wajib mendapatkan pemenuhan dan perlindungan khusus dari negara sesuai dengan ketentuan Pasal 28B ayat (2) UndangUndang Dasar Negara Republik Indonesia Tahun 1945 yang menyatakan bahwa "anak berhak atas kelangsungan hidup, tumbuh, dan berkembang serta berhak atas perlindungan dari kekerasan dan diskriminasi". Terorisme merupakan fenomena yang sangat kompleks Sebagai fenomena politik kekerasan, pengaturan terorisme tidak dapat dengan mudah dirumuskan. Tindak kekerasan itu dapat dilakukan oleh individu, kelompok ataupun negara. ${ }^{6}$ Pesatnya arus globalisasi dan dampak negatif dari perkembangan di bidang teknologi informasi dan komunikasi, memunculkan fenomena baru anak menjadi pelaku dalam tindak pidana terorisme.

Anak pelaku tindak pidana terorisme merupakan kejahatan serius (serious crimes) yang semakin meningkat dari waktu ke waktu dan secara signifikan mengancam dan membahayakan jiwa anak, merusak kehidupan pribadi dan tumbuh kembang anak, serta mengganggu keamanan, dan ketertiban masyarakat. Anak-anak yang dilibatkan dalam suatu tindak pidana teroris perlu mendapat perlakuan khusus karena dalam proses penangkapan, pemeriksaan dan peradilan harus diupayakan untuk menghindari adanya dampak buruk terhadap pertumbuhan dan

\footnotetext{
${ }^{5}$ H. Santhos Wachjoe Prijambodo. 2018. Bunga Rampai Hukum dan Filsafat di Indonesia. Yogyakarta. Deepublish CV. Budi Utama. 1.

6 Ali Masyhar \& Ridwan Arifin. 2018. Urgensi Pembentengan Masyarakat dari Radikalisme dan Terorisme. Jurnal Pengabdian Hukum Indonesia (Indonesian Journal of Legal Community Engagement). Semarang 1: Nomor $1 . \quad 10-11$ atau https://journal.unnes.ac.id/sju/index.php/JPHI/index
} 
perkembangan fisik dan psikis anak-anak yang terlibat langsung dalam tindak pidana terorisme. Oleh karena itu, dalam proses penangakapan, pemeriksaan, dan peradilan harus memperhatikan pemenuhan hak-hak anak atau kepentingan terbaik bagi anak sebagaimana yang telah diatur dalam Pasal 21 ayat (1) Undang-Undang Nomor 35 Tahun 2014 tentang Perubahan Atas Undang-Undang Nomor 23 Tahun 2002 tentang Perlindungan Anak, yang menyatakan bahwa "Negara, Pemerintah, dan Pemerintah Daerah berkewajiban dan bertanggung jawab menghormati pemenuhan Hak Anak tanpa membedakan suku, agama, ras, golongan, jenis kelamin, etnik, budaya dan bahasa, status hukum, urutan kelahiran, dan kondisi fisik dan/atau mental".

Dalam proses pemeriksaan dan peradilan perlu adanya pendampingan bagi anak-anak yang terlibat dalam jaringan terorisme baik itu dari Komisi Perlindungan Anak Indonesia (KPAI) maupun Komisi Perlindungan Anak yang ada di daerah, Pusat Pelayanan Terpadu Pemberdayaan Perempuan dan Anak (P2TP2A), pekerja sosial professional, dan tenaga kesejahteraan sosial, Badan Nasional Penanggulangan Terorisme (BNPT) dan sebagainya sehingga dapat menjalankan fungsinya dalam pengawasan, pembimbingan dan pendampingan terhadap anak baik itu didalam peradilan maupun diluar peradilan. ${ }^{7}$

Suatu tindak pidana terorisme dengan modus kekerasan maupun bom bunuh diri, dII yang melibatkan anak-anak merupakan masalah yang serius yang dihadapi oleh Negara Kesatuan Republik Indonesia. Berbagai cara yang telah dilakukan oleh pihak-pihak terkait melalui diskusi, kajian-kajian ilmiah/pertemuan-pertemuan ilmiah, maupun seminar, untuk mencari solusi terbaik atau yang dianggap tepat atas kejahatan terorisme yang melibatkan anak secara langsung dalam aksi bom bunuh diri yang sangat meresahkan masyarakat dengan menimbulkan ketakutan bagi masyarakat.

\footnotetext{
${ }^{7}$ Ahmad Mahyani. 2019. Perlindungan Hukum Anak Sebagai Pelaku Terorisme.Jurnal Hukum Magnus Opus. II : Nomor 2. 50.
}

\section{B. Rumusan Masalah}

Berdasarkan latar belakang permasalahan yang telah dikemukakan di atas, maka dapat dirumuskan beberapa masalah sebagai berikut

1. Bagaimanakah Pengaturan dan Pandangan Hak Asasi Manusia mengenai Pemenuhan Hak Anak sebagai Pelaku Tindak Pidana Terorisme?

2. Bagaimanakah Implementasi Pengaturan mengenai Pemenuhan Hak Anak sebagai Pelaku Tindak Pidana Terorisme?

\section{Tujuan Penelitian}

Berdasarkan latar belakang dan rumusan masalah yang menjadi fokus pembahasan dan penelitian, maka tujuan penelitian ini adalah sebagai berikut :

1. Untuk mengkaji dan menganalisis pengaturan hukum tentang Pemenuhan Hak-Hak Anak sebagai Pelaku Tindak Pidana Terorisme..

2. Untuk mengkaji dan menganalisis penerapan hukum terhadap Pemenuhan Hak-Hak Anak sebagi Pelaku Tindak Pidana Terorisme.

\section{METODE PENELITIAN}

\section{A. Tipe Penelitian}

Pendekatan yang digunakan dalam penelitian ini antara lain status approach (pendekatan perundang-undangan) dan analytical or conceptual approach (pendekatan analitik atau konseptual). Pendekatan UndangUndang dilakukan dengan menelaah semua Undang-Undang dan regulasi yang bersangkut paut dengan isu hukum yang terjadi. Pendekatan perundang-undangan dalam penelitian hukum normatif memiliki kegunaan baik secara praktis maupun akademis. Sedangkan pendekatan konseptual beranjak dari pandangan-pandangan dan doktrindoktrin yang berkembang didalam ilmu hukum ${ }^{8}$.

Dengan mempelajari pandanganpandangan dan doktrin-doktrin di dalam ilmu hukum, peneliti menemukan ide-ide yang terkait dengan pengertian-pengertian hukum, konsep-konsep hukum, dan asas-asas hukum

\footnotetext{
${ }^{8}$ Peter Mahmud Maruki. 2005. Penelitian Hukum. Jakarta : Kencana Prenada Media Group. 93.
} 
yang relevan dengan isu hukum yang dihadapi. Pemahaman akan pandangan-pandangan dan doktrin-doktri tersebut merupakan sandaran bagi peneliti dan membangun suatu argumentasi hukum dalam memecahkan isu yang dihadapi ${ }^{9}$.

Dengan mengacu pada pernyataan penelitian pada rumusan masalah, dimana penelitian ini menggunakan pendekatan kualitatif dengan metode yuridis normatif. Kegiatan deskripsi, sistematis, dan interpretasi hukum positif sangat bertumpu pada konsepkonsep hukum yang relevan. Konsep-konsep hukum itu perlu dijelaskan supaya dapat berdaya guna untuk kegiatan deskripsi, sistematis, dan interpretasi tersebut. Karena itu, pendekatan konseptual juga sangat penting dalam setiap penelitian hukum.

Problematika dalam ilmu hukum adalah menjawab pertanyaan atau memberikan penyelesaian masalah yang ditimbulkan oleh keraguan yang berkenaan dengan berlakunya hukum positif ${ }^{10}$. Pertanyaan pokoknya adalah mengacu dan dalam rangka tatanan hukum yang berlaku, apa hukumnya yang paling tepat atau yang paling dapat diterima bagi situasi konkret tertentu. Ini berarti menentukan apa yang menurut hukum yang berlaku menjadi hak dan kewajiban para pihak yang terlibat dalam situasi konkret itu, yang pelaksanaannya dapat dipaksakan secara sah, berbentuk sebuah putusan.

Jadi sesungguhnya objek telaah ilmu hukum terdiri atas dua unsur yang berkaitan, yakni fakta kemasyarakatan dan kaidah hukum. Pengetahuan yang dicari dalam ilmu hukum adalah tentang cara penerapan kaidah hukum secara benar. Karena itu, dari keseluruhan konstelasi kenyataan tertentu, hanya data yang yuridis relevan, yakni yang penting untuk penerapan kaidah hukum, yang dipilih atau dikualifikasi sebagai fakta. Ciri khas penalaran hukum, yaitu sebagai berikut: ${ }^{11}$

1. Penalaran hukum berusaha mewujudkan konsistensi dalam aturan-aturan hukum dan putusan-putusan hukum. Dasar pemikirannya adalah keyakinan bahwa

\footnotetext{
${ }^{9}$ Ibid. 95.

${ }^{10}$ Dr. Amiruddin \& Prof. Dr. H. Zainal Asikin. 2016. Pengantar Metode Penelitian Hukum. Cetakan ke-9. Jakarta: PT RajaGrafindo Persada. 109-110.

${ }^{11}$ Id. 116-117.
}

hukum harus berlaku sama bagi semua orang termasuk ke dalam yurisdiksinya. Kasus yang harus diberi putusan yang sama berdasarkan asas similia similibus (persamaan).

2. Penalaran hukum berusaha memelihara kontinuitas dalam waktu (konstistensi historical). Penalaran hukum akan mengacu pada aturan-aturan hukum yang sudah terbentuk sebelumnya dan putusanputusan hukum terdahulu sehingga dapat menjadi stabilitas dan prediktabilitas.

3. Dalam penalaran hukum terjadi dialektikal, yaitu menimbang-nimbang klaim yang berlawanan, baik dalam perdebatan pada pembentukan Undang-Undang maupun proses mempertimbangkan pandangan dan fakta yang diajukan.

\section{B. Jenis Data}

Data sekunder berupa penelitian kepustakaan yang dilakukan terhadap berbagai macam sumber-sumber bahan hukum yang dapat diklasifikasi menjadi 3 (tiga) jenis, yaitu ${ }^{12}$ :

1. Bahan hukum primer (Primary Resource atau authoritative records), berupa:

2. Bahan hukum sekunder (Secondary resource atau not authoritative records), berupa bahan-bahan hukum yang dapat memberikan kejelasan terhadap bahan hukum primer, seperti literature, hasilhasil penelitian, makalah-makalah dalam seminar, artikel-artikel yang berkaitan dengan hak anak pelaku tindak pidana terorisme dan maraknya tindakan radikalisme yang mengarah pada tindak pidana terorisme yang timbul dilingkungan masyarakat.

3. Bahan Hukum tersier, berupa bahanbahan hukum yang dapat member petunjuk dan kejelasan terhadap bahan hukum primer maupun bahan hukum sekunder seperti kamus, ensiklopedia, dan sebagainya yang terutama berkaitan dengan hak anak pelaku tindak pidana terorisme.

\footnotetext{
${ }^{12}$ Soerjono Soekanto \& Sri Mamudji. 2006. Penelitian Hukum Normatif. Jakarta : PT. Radja Grafindo Persada.
} 13. 


\section{Teknik Pengumpulan Data}

Untuk memperoleh hasil yang akurat dan signifikan, data yang dikumpulkan melalui studi pustaka yang dihimpun dan diolah dengan melakukan pendekatan yuridis normatif. Data yang diperoleh dimaksudkan untuk mendapat konsepsi, teori, doktrin, dan pendapat atau pemikiran konseptual dari penelitian terdahulu yang berhubungan dengan objek telaahan penelitian ini, dimana penelitian hukum normatif disebut juga penelitian hukum doktrinal ${ }^{13}$. Hukum dikonsepkan sebagai apa yang tertulis dalam peraturan perundang-undangan (Law In Books) atau hukum dikonsepkan sebagai kaidah atau norma yang merupakan patokan berprilaku manusia yang dianggap pantas. Dari perspektif tujuannya penelitian hukum normatif melalui inventarisasi hukum positif yang merupakan kegiatan pendahuluan yang sangat mendasar. Sebelum menemukan norma hukum incontreto haruslah diketahui lebih dahulu, hukum positif apa yang berlaku ${ }^{14}$. Kegiatan menginventarisasi hukum positif adalah proses identifikasi yang kritis-analitis serta logissistematis. Menginventarisasi hukum positif biasanya tidak berdiri sendiri, melainkan merupakan salah satu tahap saja dari serangkaian proses penelitian yang menyeluruh, walaupun bersifat penelitian pendahuluan, akan tetapi bernilai penting bagi penelitian hukum yang lain.

Adapun teknik pengumpulan data studi kepustakaan pada penelitian ini dengan cara sebagai berikut:

1. Menginventarisir peraturan perundangundangan yang terkait dengan masalah pemenuhan hak anak sebagai pelaku tindak pidana terorisme yang harus memperoleh jaminan perlindungan hukum.

2. Menginventarisir bahan-bahan sekunder yang relevan dengan perumusan masalah dan tujuan dari penelitian ini.

3. Mengumpulkan data dari internet.

\section{Teknik Analisis Data}

Analisis Data merupakan proses mengorganisasikan dan mengurutkan data

\footnotetext{
${ }^{13}$ Peter Mahmud Marzuki, 2010. Penelitian Hukum. Jakarta : Kencana. 36.

${ }^{14}$ Dr. Amiruddin \& Prof. Dr. H. Zainal Asikin. Loc.Cit.121.
}

kedalam kategori dan satuan uraian dasar sehingga dapat menemukan tema dan dapat dirumuskan hipotesis kerja seperti yang disarankan oleh data. Data yang telah dikumpulkan dengan studi kepustakaan tersebut selanjutnya dianalisis dengan menggunakan metode kualitatif yang didukung oleh logika berpikir secara deduktif. Analisis untuk data kualitatif dilakukan dengan cara pemilihan terhadap pasal-pasal yang berisi kaidah-kaidah hukum yang mengatur tentang pemenuhan hak-hak anak dan menelaah sinkronisasi suatu peraturan perundangundangan baik secara vertikal dengan melihat hierarkisnya ${ }^{15}$, dengan memperhatikan asas perundang-undangan dan secara horizontal diteliti sejauhmana peraturan perundanganundangan yang mengatur pelbagai bidang itu mempunyai hubungan fungsional secara konsisten. Penelitian ini juga dapat mengungkapkan kelemahan-kelemahan yang ada pada perundang-undangan dan dapat dibuat rekomendasi agar perundang-undnagan tersebut dapat diamandemen sehingga dari analisis data ini dapat ditemukan suatu jawaban dari permasalahan mengenai pemenuhan hak terhadap anak sebagai pelaku tindak pidana terorisme.

\section{HASIL DAN PEMBAHASAN}

A. Pengaturan mengenai Pemenuhan Hak Anak sebagai Pelaku Tindak Pidana Terorisme

1. United Nation Universal Declaration of Human Rights (UDHR) 1948, Resolution 217 A (III)

Pengaturan mengenai Hak Asasi Anak yang merupakan bagian dari Hak Asasi Manusia sebagaimana dituangkan dalam mukadimah Deklarasi Universal Hak-Hak Asasi Manusia (DUHAM), menyatakan bahwa pengakuan atas martabat alamiah dan hak-hak yang sama dan tidak dapat dicabut dari semua anggota keluarga manusia adalah dasar kemerdekaan, keadilan dan perdamaian di dunia (recognition of the inherent dignity and of the equal and inalienable rights of all members of the human family is the foundation of freedom, justice and peace in the world).

\footnotetext{
${ }^{15} / d .129$.
} 
2. Convention on the Rights of the Child 1989 (CRC) , Resolution 44/25

3. International Covenant on Civil and Political Rights (ICCPR) 1966 dan International Covenant on Economic, Social and Cultural Rights (ICESCR) 1966

\section{Hak Asasi Manusia}

Dalam reglemen hukum internasional telah mengatur terkait dengan pemenuhan hak-hak anak baik secara umum maupun secara khusus anak yang berhadapan dengan hukum dan/atau anak sebagai pelaku tindak pidana terorisme, sampai saat ini Majelis Umum PBB telah merampungkan berbagai konvensi dan instrumen hukum terkait penanggulangan terorisme dan Hak Asasi Manusia (Anak). Berikut konvensi-konvensi yang telah dirampungkan oleh Majelis Umum PBB: ${ }^{16}$

1. Convention on Offence and Certain Acts Committed on Board Aircraft (Konvensi Tokyo 1963) (Konvensi Tentang Pelanggaran-Pelanggaran dan Tindakan-Tindakan Tertentu lainnya yang dilakukan di dalam Pesawat Udara); ${ }^{17}$ Indonesia meratifikasinya dengan Undang-Undang Nomor 2 Tahun 76 tentang Pengesahan Konvensi Tokyo 963, Konvensi The Hague 1970, dan Konvensi Montreal 1971), dengan persyaratan (reservation) terhadap Pasal 24 ayat (1) tentang Penyelesaian perselisihan mengenai penafsiran atau penerapan konvensi ini.

2. Convention Against Torture And Other Cruel, Inhuman Or Degrading Treatment Or Punishment (Konvensi Menentang Penyiksaan Dan Perlakuan Atau Penghukuman Lain Yang Kejam, Tidak Manusiawi, Atau Merendahkan Martabat Manusia); diratifikasi dengan Undang-Undang Nomor 5 Tahun 1998.

3. Convention on the Rights of the Child (1989) (Konvensi tentang Hak-Hak Anak); Indonesia meratifikasi dengan Keputusan Presiden Nomor 36 Tahun 1990.

\footnotetext{
${ }^{16}$ Abdussalam. 2006. Hukum Pidana Internasional 2. Jakarta : Restu Agung. 1.

${ }^{17}$ http://www.dpr.go.id/index/link..dikutip pada Sabtu, 23 mei 2020, pukul 3:24 WITA
}

4. Convention for the Suppresion of Unlawful Seizure of Aircraft ( Konvensi The Hague 1970) (Konvensi Tentang Pemberantasan Penguasaan Pesawat Udara Secara Melawan Hukum); Indonesia meratifikasinya dengan Undang-Undang Nomor 2 Tahun 76 tentang Pengesahan Konvensi Tokyo 963, Konvensi The Hague 1970, dan Konvensi Montreal 1971), dengan persyaratan (reservation) terhadap Pasal 12 ayat (1) tentang Penyelesaian perselisihan mengenai penafsiran atau penerapan konvensi ini.

5. Convention for the Suppresion of Unlawful Acts Againts the Safett of Civil Aviation (Konvensi Montreal 1971) (Konvensi Tentang Pemberantasan Tindakan-Tindakan Melawan Hukum Yang Mengancam Keamanan Penerbangan Sipil); Indonesia meratifikasinya dengan Undang-Undang Nomor 2 Tahun 76 tentang Pengesahan Konvensi Tokyo 963, Konvensi The Hague 1970, dan Konvensi Montreal 1971), dengan persyaratan (reservation) terhadap Pasal 14 ayat (1) tentang Penyelesaian perselisihan mengenai penafsiran atau penerapan konvensi ini.

6. Convention on the Prevention and Punishment of Crimes against internationally Protected Persons, including Diplomatic Agents (New York, 1973) (Konvensi Tentang Pencegahan dan Hukuman Atas Kejahatan Terhadap Orang-Orang yang Secara Internasional dilindungi Termasuk Agen-agen Diplomatik);

7. International Convention against the Taking of Hostages (1979) (Konvensi Tentang Penyanderaan);

8. Universal Declaration of Human Right (UDHR) 1948 (Deklarasi Universal Hak Asasi Manusia).

9. International Covenant on Civil and Political Right (ICCPR)

10. Convention on the Physical Protection of Nuclear Material (1980) (Konvensi Tentang Perlindungan Fisik dari Material Nuklir); 
11. Convention for the Suppression of Unlawful Acts Against the Safety of Maritime Navigation (1988) (Konvensi Tentang Pemberantasan Tindakan Melawan Hukum Terhadap Keselamatan Navigasi Maritim);

12. Protocol for the Suppression of Unlawful Acts of Violence at Airports Serving International Civil Aviation (1989) (Protokol Tentang Pemberantasan Tindakan Melanggar Hukum Kekerasan di Bandara Melayani Penerbangan Sipil Internasional);

13. Protocol for the Suppression of Unlawful Acts Against the Safety of Fixed Platforms Located on the Continental Shelf (1988) (Protokol Tentang Pemberantasan Tindakan Melanggar Hukum Terhadap Keselamatan Dasar Tetap yang Terletak di Landas Kontinental); ${ }^{18}$

14. Convention on the Marking of Plastic Explosives for the Purpose of Detection (1993) (Konvensi Tentang Penandaan Bahan Peledak Plastik untuk Tujuan Pendeteksian);

15. International Convention for the Suppression of Terrorist Bombing (1977) (Konvensi Internasional Tentang Pemberantasan Pengeboman Teroris);

- International Convention for the Suppression of Terrorist Bombing (1977) (Konvensi Internasional Tentang Pemberantasan Pengeboman Teroris);

- International Convention for the Suppression of the Financing of Terrorism (1999) (Konvensi Internasional Tentang Pemberantasan Pendanaan Terorisme);

- International Convention on the Suppression of Acts of Nuclear Terrorism (2005) (Konvensi Internasional untuk Pemberantasan Tindakan Terorisme Nuklir);

- Convention on the Suppression of Unlawful Acts Relating to International Civil Aviation (2010)
(Konvensi Pemberantasan

Tindakan Melawan Hukum yang berkaitan dengan Penerbangan Sipil Internasional).

Sekitar lima puluh pelanggaran sudah ditentukan didalam tiap-tiap konvensi, tersebut, termasuk didalamnya sepuluh kejahatan terhadap penerbangan sipil; dua belas kejahatan terhadap orang lain; tujuh kejahatan terhadap penggunaan, kepemilikan, serta pengancaman menggunakan bom atau material nuklir, dan dua kejahatan terkait dengan pendanaan terorisme. ${ }^{19}$ Sejak awal tahun 1990-an, Dewan Keamanan PBB telah secara konsisten menangani masalah terorisme. Memberikan tindakannya berupa sanksi terhadap negara-negara yang terbukti memiliki hubungan dengan tindakan terorisme tertentu, seperti Libya (1992), Sudan (1996), dan Taliban (1999 dan diperluasn mencakup Al-Qaida pada tahun 2000 melalui resolusi 1333). Sebelum serangan teroris 11 september 2001 terhadap Amerika Serikat, Dewan Keamanan telah membentuk alat kontraterorisme yang kuat, yakni Komite 1267 (terdiri dari semua anggota dewan) didirikan pada tahun 1999 melalui resolusi 1267 dan bertugas memantau sanksi melawan Taliban (dan kemudian Al-Qaida pada tahun 2000). Atas permintaan Dewan Keamanan PBB, Sekretaris Jenderal menunjuk dukungan analitis dan Tim Pemantau Sanksi untuk membantu Komite. Tim terdiri dari para ahli dalam kontraterorisme dan masalah hukum, terkait embargo senjata, larangan perjalanan dan pendanaan teroris. ${ }^{20}$

Anak sebagai pelaku tindak pidana terorisme merupakan kejahatan serius (serious crimes) yang semakin meningkat dari waktu ke waktu dan secara signifikan mengancam dan membahayakan jiwa anak, merusak kehidupan pribadi dan tumbuh kembang anak, serta mengganggu rasa kenyamanan, ketentraman, keamanan, dan ketertiban masyarakat. Anak juga merupakan bagian dari masyarakat, bangsa dan negara yang hak-haknya harus

\footnotetext{
19 http://www.icrc.org/eng/resource/documents Larticle/review/review-864-p853.htm. dikutip pada Jumat. 22 mei 2020. pukul 9:15 WITA.

${ }^{20}$ I Gede Pasek Eka Wisanjaya. 2016. Pengaturan tentang Terorisme dalam Hukum Internasional dan Hukum Nasional. 23.
} 
dihormati dan dilindungi sebagaiman termuat dalam Undang-Undang Dasar 1945 dan Konvensi Perserikatan Bangsa-Bangsa tentang Hak-Hak Anak. Dalam pandangan kehidupan berbangsa dan bernegara, anak adalah masa depan bangsa selaku generasi penerus cita-cita bangsa sehingga setiap anak berhak atas kelangsungan hidup, tumbuh dan berkembang (tumbang), berpartisipasi serta berhak atas pemenuhan hak-haknya dan perlindungan dari diskriminasi karena hak asasi anak anugerah dari Tuhan yang wajib dihormati, dijunjung tinggi, dan dilindungi oleh negara, hukum, pemerintah, dan setiap orang demi kehormatan serta perlindungan harkat dan martabat sebagai manusia.

Hak Asasi Anak adalah hak asasi manusia yang memperoleh perlindungan dari negara ${ }^{21}$, sebagai salah satu yang disebut oleh negara hukum, yaitu ditegakkannya hak asasi manusia sehingga negara hukum tanpa mengakui, menghormati sampai melaksanakan sendirsendi hak asasi manusia terkait dengan pemenuhan hak anak pelaku tindak pidana, menurut A.V. Dicey terdapat tiga unsur, yaitu:

1. Hak asasi manusia dijamin lewat UndangUndang,

2. Persamaan kedudukan di muka hukum (Equality before the law),

3. Supremasi aturan-aturan hukum

(supremacy of law) dan tidak adanya

kesewenang-wenangan tanpa aturan yang jelas.

Secara khusus pengaturan tentang pemenuhan hak anak termuat dalam DUHAM dan Konvensi Hak-Hak Anak yang mengikat seluruh negara anggota PBB menunjukkan bagaimana hak asasi manusia dilindungi tanpa adanya perlindungan hukum yang disepakati bersama, nasib hak asasi manusia hanya akan merupakan suatu kekuatan potensial yang sulit direalisasikan dalam negara. Hak asasi manusia berlaku bagi semua orang (Universal) tanpa terkecuali. Atas dasar kesadaran itulah maka lahirlah Deklarasi Universal Hak Asasi Manusia (Universal Declaration of Human Rights (UDHR) tahun 1948. Dengan diratifikasinya DUHAM di Indonesia dan Konvensi Hak-Hak Anak tahun 1990 merupakan sarana

\footnotetext{
${ }^{21}$ Insan Firdaus. 2015. Penghapusan Diskriminasi dan Kekerasan Terhadap Anak. Warta Hak Asasi Manusia Humanis : 1: 15-17.
}

penangkal yang tepat untuk mencegah terjadinya kecenderungan pelanggaran hak asasi manusia.

\section{B. Implementasi mengenai Pengaturan \\ Pemenuhan Hak Anak sebagai Pelaku Tindak Pidana Terorisme}

Penerapan pemenuhan dan perlindungan hak asasi anak sebagai Pelaku Tindak Pidana Terorisme di Negara-negara berkembang dipengaruhi oleh berbagai faktor, baik itu faktor politik, ekonomi dan kebijakan pemerintah. Di Indonesia, penegakan hak asasi anak telah direalisasikan dengan diratifikasinya Convention on the Rights of the Child (CRC), berdasarkan Keputusan Presiden Nomor 36 Tahun 1990 tentang Pengesahan Konvensi Hak Anak, sebagaimana yang tersirat didalamnya, yakni bahwa "bahwa umat manusia berkewajiban memberikan yang terbaik bagi anak-anak dalam pemeliharaan dan bantuan khusus yang diperlukan serta perlindungan hak asasi anak".Terkait dengan pemenuhan hak anak sebagai Pelaku Tindak Pidana Terorisme atas kebutuhan anak baik secara fisik maupun psikis masih terdapat berbagai kendala dalam merealisasikannya.

Tindak Pidana Terorisme dengan modus melibatkan anak dalam berbagai tindakan radikal maupun aksi bom bunuh diri yang terjadi secara global dan di Indonesia khususnya, sehingga menjadi perhatian publik, berbagai media (CNN, VOA, Okezone, dII) mencatat ada beberapa kasus Tindak Pidana Terorisme yang melibatkan anak secara langsung atau anak sebagai pelaku teror. Menurut Irjen Arief Dharmawan, selaku Deputi Penindakan dan Pembinaan Kemampuan Badan Nasional Penanggulangan Terorisme (BNPT), bahwa Teroris menggunakan perempuan dan anak-anak meninggalkan metode klasik bunuh diri oleh lelaki dewasa, tengah menggejala di dunia teror khususnya mereka yang terpengaruh oleh kelompok Islamic State. ${ }^{22}$ Gejala ini sudah biasa di Suriah dan Irak dimana anak-anak usia 9 sampai 10

\footnotetext{
${ }^{22}$ Ninis Chairunnisa.Pelaku Bom di Surabaya Satu Keluarga.Begini Pembagian Tugasnya.https://nasional.tempo.co/read/1088460/pela ku-bom-di-surabaya-satu-keluarga-begini-pembagiantugasnya. (Tempo 2018) diakses pada rabu. 8 Januari 2019. pukul 8:15 WITA
} 
tahun sudah disiapkan untuk melakukan aksi bom bunuh diri, begitu pula di Indonesia terdapat anak-anak yang berusia 13 tahun sudah terpapar ide radikal ini dan lalu beraksi pada usia 15 sampai 16 tahun.

Pemberantasan tindak pidana Terorisme di Indonesia tidak semata-mata merupakan masalah hukum dan penegakan hukum, melainkan juga merupakan masalah ekonomi, sosial, dan budaya. Masalah ekonomi menjadi dasar faktor pendukung lahirnya Radikalisme dan Terorisme sebagai akibat dari rasa frustrasi dari kelompok orang miskin yang tidak bisa bertahan dalam kehidupannya, sehingga terpengaruh untuk melakukan perbuatan yang mengarah kepada Radikalisme dan Terorisme.

Dalam Penerapan instrumen hukum Nasional maupun hukum Internasional terkait dengan peran perempuan dan anak-anak yang terlibat dalam tindak pidana terorisme dan / atau yang berafiliasi dengan ISIS, membutuhkan berbagai kajian dan pertimbangan dalam menerapkan suatu regulasi terhadap eksistensi perempuan dan anak-anak mengenai nasib dan masa depan anak-anak. Peran Perempuan sebagai seorang isteri dan ibu dari anak-anak tidak dapat dipisahkan sehingga dalam hal ini, apabila perempuan dilibatkan dan atau melibatkan diri dalam organisasi kejahatan terorisme akan sangat berbahaya bagi masa depan anak-anak dan bahkan orang banyak.

Upaya pemenuhan hak anak berkaitan erat dengan suatu tindakan proaktif atas repatriasi terhadap perempuan dan anak-anak Pejuang Teroris Asing (Foreign Terrorist Fighters) menjadi sebuah polemik bagi bangsa dan negara. Negara melakukan pendekatan (approach) secara toleran terhadap pemulangan perempuan dan anak-anak anggota Pejuang Teroris Asing (FTF) pada gelombang pertama dan kedua tahun 20032014 dan pada awal tahun $2015,{ }^{23}$ dengan asumsi bahwa peran mereka hanya sebagai tambahan atau pendukung. Oleh karena itu, hal tersebut tidak dapat menimbulkan ancaman yang signifikan bagi keamanan nasional. Namun demikian, pandangan dan

\footnotetext{
${ }^{23}$ Fransesca Capone.2019.The children (and wives) of foreign ISIS fighters: Which obligations upon the States of nationality? QIL, Zoom-in 60. 74-75
}

asumsi dari masyarakat dan kalangan intelek terjadi pro dan kontra terhadap ancaman dan keamanan nasional.

Peran proaktif perempuan dan anak-anak perempuan terjadi pergeseran dalam posisi ISIS tentang status perempuan dalam peran tempur, yang terjadi antara tahun 2015 dan 2018. Kelompok itu sendiri dilemahkan oleh serangan angkatan bersenjata dan meningkatnya kekalahan militer yang memungkinkan perempuan untuk melakukan peran yang lebih aktif dengan secara terbuka menyatakan bahwa "hal itu wajib dilakukan perempuan untuk mengangkat senjata (it is obligatory for women to take up arms)'. Seperti diketahui, sejak berdirinya kekhalifahan, perempuan menjadi anggota brigade Al-Khansaa dan telah aktif terlibat dalam propaganda dan perekrutan secara online, merawat perempuan yang lain dan anak-anak perempuan.

Konvensi Hak Anak merupakan wujud nyata atas upaya pemenuhan hak anak sebagai pelaku tindak pidana terorisme, agar hidup anak menjadi lebih baik. ${ }^{24}$ Sejak Indonesia meratifikasi Konvensi Hak Anak pada Tahun 1990 adanya kemajuan yang telah ditunjukkan oleh pemerintah Indonesia dalam melaksanakan Konvensi Hak Anak. Dalam menerapkan Konvensi Hak Anak, negara peserta konvensi berkewajiban untuk menghormati dan melaksanakan ketentuanketentuan, aturan-aturann dalam kebijakan, program dan tata laksana pemerintahannya. Konvensi Hak Anak merupakan sebuah perjanjian yang mengikat, yang artinya ketika disepakati oleh suatu negara, maka negara tersebut terikat pada janji-janji yang ada di dalamnya dan negara wajib untuk melaksanakannya.

Konvensi Hak Anak (Convention on the Rights of the Child) merupakan sebuah perjanjian hukum international tentang hakhak anak. Konvensi ini secara sederhana dapat dikelompokkan kedalam 3 hal. Pertama, mengatur tentang pihak yang berkewajiban menanggung tentang hak yaitu negara. Kedua, pihak penerima hak yaitu anak-anak. Ketiga, memuat tentang bentuk-bentuk hak yang

\footnotetext{
24 Zulfikar Judge. 2016. Kedudukan Anak Yang Berhadapan Dengan Hukum Selaku Pelaku Tindak Pidana.
} Lex Jurnalica. FH-UEU Jakarta.13 No. 3 : 223-224. 
harus dijamin untuk dilindungi, dipenuhi dan ditingkatkan. Indonesia sendiri meratifikasi Konvensi Hak Anak (Convention on the Rights of the Child) melalui Keputusan presiden Nomor. 36 tahun 1990 pada tanggal 25 Agustus 1990.

Pasal 29 menyatakan bahwa "Negaranegara Pihak sependapat bahwa pendidikan anak harus diarahkan untuk" ${ }^{25}$ :

(a) Pengembangan kepribadian, bakat dan kemampuan mental dan fisik anak hingga mencapai potensi mereka sepenuhnya;

(b) Pengembangan penghormatan terhadap hak asasi manusia dan kebebasan dasar, dan atas prinsip-prinsip yang diabadikan dalam Piagam Perserikatan Bangsa-Bangsa;

(c) Pengembangan rasa hormat kepada orangtua anak, identitas budaya, bahasa dan nilai-nilainya sendiri, kepada nilai-nilai nasional negara tempat anak bermukim, anak berasal, dan penghormatan kepada peradaban-peradaban yang berbeda dari peradabannya sendiri;

(d) Penyiapan anak untuk kehidupan yang bertanggungjawab dalam suatu masyarakat yang bebas, dalam semangat saling pengertian, perdamaian, toleransi, kesetaraan jenis kelamin, dan persahabatan antar semua bangsa, suku bangsa, kelompok nasional dan agama, dan orangorang yang termasuk penduduk asli;.

(e) Pengembangan rasa hormat pada lingkungan alamiah.

Sekalipun demikian anak sebagai pelaku tindak pidana terorisme, namun tidak dapat dihilangkan haknya untuk memperoleh pendidikan yang layak sehingga ketika anak berada dalam situasi dimana anak ditahan, atau berada dalam proses hukum juga rehabilitasi tidak mengurangi waktunya untuk belajar, bermain dan lain sebagainya, anak-anak perlu diarahkan dengan tepat sesuai dengan kebutuhannya sehingga tercapainya pemenuhan dan perlindungan hak anak guna untuk tujuan kesejahteraan anak.

Proses rehabilitasi untuk anak-anak adalah kunci mutlak untuk mencegah terjadinya radikalisasi di dalam penjara dan mendukung anak-anak yang telah diradikalisasi untuk

\footnotetext{
${ }^{25}$ Children's Rights Alliance. 2013. Summary of the UN Convention on the Rights of the Child. 3.
}

berhenti dan mengintergrasikan diri kembali pada kebebasan. Hal ini apakah berada di daerah konflik atau atau pada kestabilan sistem peradilan anak-anak. Anak-anak memiliki kemampuan rehabilitasi meliputi bentuk hubungan yang konstruktif dengan dasar kepercayaan terhadap pihak terkait, mengembangkan rasa optimisme tentang masa depan anak setelah dibebaskan, mengembangkan pendidikan, pelatihan dan pekerjaan serta hubungan dengan keluarga dan teman (sejauh itu untuk kepentingan terbaik anak). Di Sri Lanka misalnya, suatu program untuk bekas pejuang LTTE, mencakup anak-anak, terdiri dari 6 (enam) bentuk rehabilitasi termasuk keterlibatan masyarakat, ${ }^{26}$ dengan julukan "model $6+1$ " yaitu:

1. Pendidikan (Educational)

2. Kejuruan (Vocational)

3. Psikososial dan terapi kreatif (Psychosocial and Creative Therapies)

4. Sosial, budaya, dan keluarga (Social, Culture, and Family)

5. Spiritual dan agama (Spiritual and religious)

6. Rekreasi (Recreational)

Proses rehabilitasi harus dimulai saat seorang anak tiba di lembaga penahanan. Seharusnyan anak itu diwawancarai saat masuk, psikologis dan laporan sosial seharusnya disiapkan. Laporan ini, bersama dengan laporan medis harus digunakan oleh lembaga terkait untuk menentukan yang paling tepat mengenai program rehabilitasi yang diusahakan. Anak-anak perempuan sering menjadi korban kekerasan berbasis gender dan membutuhkan dan membutuhkan dukungan khusus sesuai gender, usia, konseling, dan penanganan kesehatan. Rehabilitasi tidak dimungkinkan dimana melebihi pihak terkait yang kurang terlatih, suasana ketakutan, kekerasan, ketidakpercayaan dan rasio anakanak yang tidak memadai atas ketersediaan pihak terkait. Hal ini akan lebih efektif bekerja bila pengaturannya cukup kecil untuk penanganan individu yang harus diberikan dan dimana anak-anak merasa aman. Anak-anak yang mengalami kondisi penahanan yang baik akan jauh lebih bersedia dan mampu merespon program rehabilitasi. Hal yang

\footnotetext{
${ }^{26}$ Id. 12
} 
sangat mendasar mereka harus ditahan terpisah dari orang dewasa, dalam kondisi fisik yang aman dan lingkungan dimana ketersediaan penanganan medis yang memadai. $^{27}$

Pihak-pihak terkait terdiri dari keahlian seperti pendidik, instruktur kejuruan, konselor, pekerja sosial, psikiater dan psikolog. Mereka perlu dilatih dalam psikologi anak, kesejahteraan anak dan standar Internasional tentang hak-hak anak agar mereka dapat melaksanakan tanggung jawab mereka secara efektif. Hukuman badan, kurungan atau isolasi, dan hukuman lainnya yang membahayakan fisik atau kesehatan mental anak sangat dilarang. Semua anak akan mendapat manfaat dari program rehabilitasi dan merupakan suatu bagian penting untuk mencegah radikalisasi selama dipenjara. Resiko ideologi yang radikal mungkin lebih jauh lebih tinggi bagi anak-anak yang merasa masa depan mereka suram dan tidak pasti. Adanya ruang khusus untuk program radikalisasi individu dan kebebasan untuk anak-anak yang dihukum karena kekerasan yang radikal atau yang telah menjadi radikal ketika ditahan. ${ }^{28}$

\section{PENUTUP}

\section{A. Kesimpulan}

1. Dari hasil penelitian menunjukkan bahwa pengaturan mengenai jaminan pemenuhan dan perlindungan hak anak sebagai Pelaku Tindak Pidana Terorisme berdasarkan instrumen hukum internasional dan instrumen hukum nasional cukup memadai, namun posisi keterlibatan anak sebagai pelaku tindak pidana terorisme tidak secara tegas dinyatakan statusnya sebagai "pelaku" dengan pertimbangan usia anak dibawah umur, sekalipun perbuatan anak memenuhi unsur-unsur dalam suatu tindak pidana terorisme tersebut.

2. Terjadinya berbagai kasus tindak pidana terorisme yang melibatkan anak didalamnya menunjukkan ketidak pastian hukum dalam penerapan

${ }^{28}$ Aleksandar Pasagic. 2019. Between Child Soldiers and Terrorists: Reintegrating Child Members of the Islamic State. Journal For Deraducalization. Kamrad. No. 2: 124125.
}

pengaturan mengenai pemenuhan dan perlindungan hak asasi anak. Adanya pro dan kontra terhadap implementasi peraturan terkait anak sebagai pelaku tindak pidana, terutama dalam penetapan sanksi atas perbuatan anak, yang dipandang selayaknya orang dewasa. Aspek lain yang mengenai ketidaktegasan pertanggung jawaban pelaku tindak pidana baik secara pribadi maupun kelompok sosial, politik terhadap tindak pidana terorisme yang dapat berpotensi akan terus berlanjut tindakan radikalisme yang mengarah pada tindak pidana terorisme.

\section{B. Saran}

1. Perlu adanya ketegasan terkait dengan posisi atau status anak sebagai pelaku tindak pidana terorisme dalam instrumen hukum internasional maupun dalam instrumen hukum nasional.

2. Untuk menekan terjadinya kembali kasus tindak pidana terorisme yang melibatkan anak, maka diperlukan adanya tindakan preventif dari semua pihak terkait dengan menindak secara tegas kelompok-kelompok radikal yang memanfaatkan anak-anak dengan berbagai modus. Perlu adanya sinergisitas dari semua pihak, baik pemerintah, masyarakat, keluarga maupun organisasi-organisasi sosial lainnya dalam program reintegrasi, rehabilitasi maupun repatriasi dalam mewujudkan tujuan deradikalisasi.

DAFTAR PUSTAKA

H. Santhos Wachjoe Prijambodo. 2018. Bunga Rampai Hukum dan Filsafat di Indonesia. Yogyakarta. Deepublish CV. Budi Utama.

Ali Masyhar \& Ridwan Arifin. 2018. Urgensi Pembentengan Masyarakat dari Radikalisme dan Terorisme. Jurnal Pengabdian Hukum Indonesia (Indonesian Journal of Legal Community Engagement). Semarang 1: Nomor 1. 10-11 atau https://journal.unnes.ac.id/sju/index. php/JPHI/index 
Ahmad Mahyani. 2019. Perlindungan Hukum Anak Sebagai Pelaku Terorisme.Jurnal Hukum Magnus Opus. II : Nomor 2.

Peter Mahmud Maruki. 2005. Penelitian Hukum. Jakarta : Kencana Prenada Media Group.

Dr. Amiruddin \& Prof. Dr. H. Zainal Asikin. 2016. Pengantar Metode Penelitian Hukum. Cetakan ke-9. Jakarta: PT RajaGrafindo Persada.

Soerjono Soekanto \& Sri Mamudji. 2006. Penelitian Hukum Normatif. Jakarta : PT. Radja Grafindo Persada.

Peter Mahmud Marzuki, 2010. Penelitian Hukum. Jakarta : Kencana.

Abdussalam. 2006. Hukum Pidana Internasional 2. Jakarta : Restu Agung.

I Gede Pasek Eka Wisanjaya. 2016. Pengaturan tentang Terorisme dalam Hukum Internasional dan Hukum Nasional.

Insan Firdaus. 2015. Penghapusan Diskriminasi dan Kekerasan Terhadap Anak. Warta Hak Asasi Manusia Humanis : 1:

Ninis Chairunnisa.Pelaku Bom di Surabaya Satu Keluarga.Begini Pembagian Tugasnya.https://nasional.tempo.co/ read/1088460/pelaku-bom-disurabaya-satu-keluarga-beginipembagian-tugasnya. (Tempo 2018) diakses pada rabu. 8 Januari 2019. pukul 8:15 WITA

Fransesca Capone.2019.The children (and wives) of foreign ISIS fighters: Which obligations upon the States of nationality? QIL, Zoom-in 60.

Zulfikar Judge. 2016. Kedudukan Anak Yang Berhadapan Dengan Hukum Selaku Pelaku Tindak Pidana. Lex Jurnalica. FH-UEU Jakarta.13 No. 3 : 223-224.

Children's Rights Alliance. 2013. Summary of the UN Convention on the Rights of the Child.

Aleksandar Pasagic. 2019. Between Child Soldiers and Terrorists: Reintegrating Child Members of the Islamic State. Journal For Deraducalization. Kamrad. No. 2: 124-125. 